\title{
AGRO CLIMATIC RISK ASSESSMENT IN HAMBANTOTA REGION
}

\section{H J P Gunarathna, C M Navaratne and KD N Weerasinghe \\ Dept. of Agric. Engineering, Faculty of Agriculture, University of Ruhuna}

In order to eliminate the risk on crop production in Hambantota region, spatial and temporal variation of rainfall were analyzed based on rainfall magnitude, duration, risk and onset. The rainfall data over 42 years $(1960-2002)$ in six rain gauge stations in Hambantota region was assessed.

$10 \mathrm{~mm}$ weekly rainfall at $75 \%$ probability level method was used to find the wet weeks in each station throughout the year. $10 \mathrm{~mm}$ weekly rainfall at $50 \%$ probability level was used for rainfall onset identification. Farmer survey was conducted to find the existing cropping calendar. The amount of rainfall, which accumulated on the date of crop commencement, was identified using Forward accumulation method.

The results revealed that mean annual rainfall is decreasing in Hambantota region. All stations were recorded less than $20 \%$ wet weeks. It reveals that the high risk involves with rain fed crop cultivation in Hambantota region. Based on the $10 \mathrm{~mm}$ weekly rainfall at $50 \%$ probability level, rainfall onset for yala and maha seasons varies from $11^{\text {th }}$ to $16^{\text {th }}$ week and from $37^{\text {th }}$ to $42^{\text {nd }}$ week respectively. The farmers could be able to minimize the irrigation need using these rainfall onset weeks as their crop commencement weeks. Based on the farmer survey, crop commencement week in maha season varies between 39 th and $41^{\text {st }}$ week and farmers rarely cultivate during yala season. According to the forward accumulation method at $75 \%$ probability level the amount of water accumulated at crop commencement time was $75 \mathrm{~mm}$. The results indicate that the crop commencement week based on farmer survey coincided with calculated rainfall onset during maha season.

Proceedings of the Ninth Annual Forestry and Environment Symposium 2003 of the Department of Forestry and Environmental Science, University of Sri Jayewardenepura, Sri Lanka 